\title{
Device Usage ICSR Terminology
}

National Cancer Institute

\section{Source}

National Cancer Institute. Device Usage ICSR Terminology. NCI Thesaurus. Code C54595.

Terminology used in Individual Case Safety Reports to specify a type of device usage, section $\mathrm{H} 8$ of FDA MedWatch Form. 